\title{
PENGARUH CAPITAL STRUCTURE DAN FIRM SIZE TERHADAP AGENCY COST DAN KINERJA KEUANGAN
}

\author{
Poppy Pujawati ${ }^{1}$, Ni Ketut Surasni ${ }^{2}$ \\ 1Program Studi Magister Manajemen Fakultas Ekonomi dan Bisnis Unram, \\ poppy_1801@yahoo.com \\ 2Fakultas Ekonomi dan Bisnis, Universitas Mataram
}

\begin{abstract}
ARTICLE INFO
Keywords :

Capital Structure, Firm Size, AgencyCost, Financial Performance.

How to cite :

Pujawati, Poppy., Surasni, Ni Ketut., (2019). Pengaruh Capital Structure dan Firm Size terhadap Agency Cost danKinerja Keuangan, JMM UNRAM 9(1),78-90

DOI :

http://dx.doi.org/10.29303/jmm.v9i1.496
\end{abstract}

Dikumpulkan : 22 September 2019

Direvisi : :27 September 2019

Dipublikasi : :03 Oktober 2019

\section{ABSTRACT}

This research is aimed at examining the effect of capital structure and firm size on agencycost and financial performance of Miscellaneous Industry which listed in BEI. The populations of this research were all Miscellaneous Industry which listed in BEI. Sampling was conducted using a purposive sampling method so that in this research the number of samples were 23 companies in the 2013-2017 period. Testing classic assumptions include normality test, multicollinearity test, heteroscedasticity test, and autocorrelation test. The collected data were then analyzed with path analysis using SPSS program and Sobel test. The research showed that there is an influence of the firm size tested has an effect on agency cost, while the capital structure has not an effect on agency cost. There is an influence of firm size, and agency cost on financial performance, while the capital structure has not an effect on the financial performance. There is an indirect effect of firm size on financial performance through agency cost as an intervening variable.

Tujuan dalam penelitian ini, yakni memberikan bukti empirik bagaimana pengaruh langsung maupun tidak langsung antara struktur modal dan ukuran perusahaan terhadap agency cost; pengaruh struktur modal, ukuran perusahaan dan agency cost terhadap kinerja keuangan perusahaan manufaktur; serta pengaruh tidak langsung struktur modal dan ukuran perusahaan melalui agency cost sebagai variabel intervening terhadap kinerja keuangan perusahaan. Populasi adalah perusahaan-perusahaan manufaktur subsektor Miscellaneous Industry yang Terdaftar di BEI periode 2013-2017. Dari populasi ini dipilih populasi sasaran yang semuanya menjadi sampel penelitian. Pengambilan sampel dilakukan dengan menggunakan metode purposive sampling sehingga dalam penelitian ini jumlah sampel 


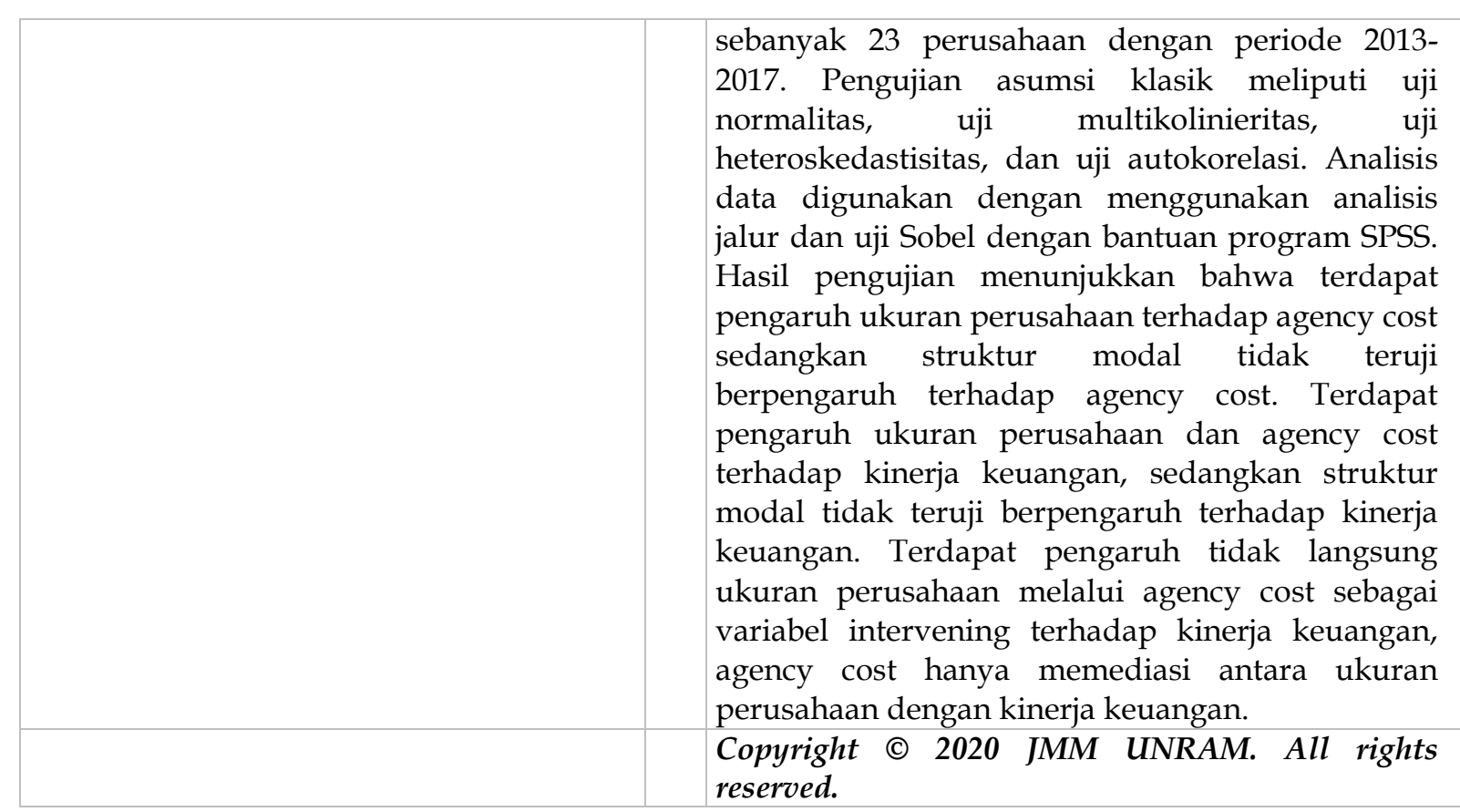

\section{PENDAHULUAN}

Kinerja keuangan suatu perusahaan ditentukan oleh struktur modal dan ukuran dari perusahaan, dimana perusahaan dengan struktur modal yang baik dan dengan ukuran perusahaan yang relatif besar cenderung memiliki kinerja yang baik (Ross et al, 2008). Selain itu Lin (2009) juga meneliti pengaruh agency cost terhadap kinerja keuangan, dimana hasil penelitian menemukan bahwa agency cost berpengaruh negatif dan signifikan terhadap kinerja keuangan. Demikian juga Wright, et al (2009) menemukan bahwa agency cost berhubungan negatif dengan kinerja keuangan perusahaan, dengan kata lain sikap tidak peduli terhadap agency cost dapat mengurangi pencapaian keuntungan kompetitif yang berdampak negatif terhadap kinerja keuangan perusahaan. Berdasarkan pada uraian teori yang telah dikemukakan, maka patut diduga bahwa struktur modal dan ukuran perusahaan berpengaruh terhadap agency cost. Selanjutnya struktur modal dapat juga berpengaruh langsung terhadap kinerja keuangan (Brigham dan Houston, 2001; dalam Fachrudin, 2011). Demikian juga ukuran perusahaan dapat berpengaruh terhadap kinerja keuangan (Calisir et al, 2010; Lin, 2009; Wright et al, 2009). Selain itu Lin (2009) dan Wright, et al (2009) menemukan bahwa agency cost berpengaruh terhadap kinerja keuangan.

Struktur modal dan ukuran perusahaan juga berpengaruh terhadap kinerja keuangan melalui agency cost sebagai variabel intervening (Fachrudin, 2011; Immanuela, 2014; Randis dan Fitriany, 2014). Artinya semakin tinggi tingkat hutang dalam struktur modal dan semakin besar ukuran perusahaan dapat berpengaruh terhadap kinerja keuangan jika dikaitkan dengan agency cost yang diproksikan dengan rasio discretionary expense terhadap penjualan bersih. Maksudnya jika hutang meningkatkan beban bunga maka discretionary expense dapat meningkat dan akibatnya menurunkan kinerja, tetapi jika beban bunga tersebut menghemat pajak maka kinerja dapat meningkat. Hutang juga mungkin meningkatkan produktifitas sehingga penjualan meningkat. Rasio discretionary expense terhadap penjualan bersih yang merupakan proksi dari agency cost berkurang, yang menyebabkan laba meningkat, dan akibatnya kinerja meningkat. Demikian juga jika ukuran perusahaan meningkatkan skala ekonomis maka kemungkinan kinerja akan meningkat melalui pengurangan discretionary expense. Sebaliknya, jika ukuran yang besar 


\section{NATIONALLY ACCREDITED J OURNAL - DECREE NO. 21/E/KPT/2018}

menyebabkan peningkatan beban, maka kinerja keuangan perusahaan akan mengalami penurunan kinerja.

Demikian pula halnya yang terjadi pada perusahaan yang terdaftar di Bursa Efek Indonesia (BEI), khususnya pada perusahaan manufaktur. Perusahaan yang bergerak di bidang manufaktur adalah perusahaan yang membuat atau menghasilkan barang dengan melakukan suatu proses mengubah bahan mentah menjadi barang siap untuk digunakan, dan dipakai atau dikonsumsi oleh manusia. Daftar perusahaan manufaktur di Indonesia sendiri sangat banyak baik dalam bentuk BUMN (Badan Usaha Milik Negara) maupun dalam bentuk swasta. Perusahaan yang bergerak di bidang industri manufaktur lebih dinamis jika dibandingkan dengan industri-industri lainnya. Hal ini dapat dibuktikan dari jumlah perusahaan yang terdaftar di BEI, dimana jumlahnya sangat fluktuatif atau selalu berubah-ubah setiap periodenya. Daftar perusahaan manufaktur Indonesia akan lebih mudah dikategorikan dalam bentuk bidang bisnisnya. Mengingat banyaknya perusahaan manufaktur terutama didominasi oleh perusahaan swasta dan luar negeri yang bergerak pada bidang industri antara lain Semen; Keramik, Kaca dan Porselin; Logam dan sejenisnya; Kimia; Plastik dan Pengepakan; Pakan Ternak; Industri Kayu; Kertas dan Pulp; Mesin dan Alat-alat Berat; Otomotif dan Komponennya; Garmen dan Tekstil; Sepatu dan Sandal; Kabel; Elektronika; Makanan dan Minuman; Industri Rokok; Farmasi; Kosmetik dan Kebutuhan Rumah Tangga; serta Peralatan Rumah Tangga. Secara umum industri manufaktur dikategorikan menjadi tiga golongan, yang telah melantai di BEI dan telah menjadi perusahaan terbuka (Tbk). Golongan industri tersebut terdiri dari Basic Industry and Chemicals (Industri Dasar dan Kimia), Miscellaneous Industry (Industri Lain-lain), dan Consumer Goods Industry (Industri Barang Konsumsi).

Miscellaneous Industry, merupakan bidang industri yang tergolong dinamis dikarenakan banyaknya perusahaan-perusahaan yang keluar masuk dalam daftar perusahaan manufaktur yang listed (terdaftar) di BEI. Berbeda halnya dengan Basic Industry and Chemicals dan Consumer Goods Industry yang cenderung memiliki daftar perusahaan lebih stabil. Perusahaan-perusahaan yang masuk dalam golongan Miscellaneous Industry itu sendiri terbagi ke dalam enam golongan, seperti Mesin dan Alat-alat Berat; Otomotif dan komponennya; Garmen dan Tekstil; Sepatu dan Sandal; Kabel; dan Elektronika. Berdasarkan data pada Lampiran 1 dapat diketahui bahwa terdapat sebanyak 23 perusahaan manufaktur industri lainnya yang listed di BEI selama periode tahun 2013 sampai tahun 2017. Perusahaan manufaktur khususnya subsektor Miscellaneous Industry mempunyai karakteristik padat modal karena merupakan jenis industri yang memerlukan modal finansial yang besar dan didukung oleh teknologi yang tinggi. Menurut Simanungkalit (2015) jenis-jenis industri ini sangat mengandalkan kemampuan karyawan, pengetahuan, teknologi, dan inovasi dalam melaksanakan kegiatan bisnisnya. Tavini (2013) menjelaskan bahwa industri manufaktur merupakan kategori perusahaan di BEI yang mempunyai peluang untuk tumbuh dan berkembang dengan pesat karena potensi pasarnya dari tahun ke tahun makin berkembang seiring dengan tingkat kebutuhan penduduk Indonesia. Dengan demikian, apabila dikaitkan dengan kondisi di atas maka perusahaan manufaktur subsektor Miscellaneous Industry menarik untuk diteliti.

\section{KAJIAN PUSTAKA}

\subsection{Pengaruh Struktur Modal terhadap Agency Cost}

Jensen (1986; dalam Budiarso, 2013) menerangkan jika perusahaan banyak utang, maka manajer akan dipaksa mengeluarkan free cash flow (aliran kas bebas) dari perusahaan untuk membayar utang, sehingga dapat mencegah pengeluaran perusahaan lainnya yang tidak penting (mengurangi arus kas yang tersedia untuk diskresioner yang digunakan 


\section{NATIONALLY ACCREDITED J OURNAL - DECREE NO. 21/E/KPT/2018}

manajemen). Hal tersebut akan memperkecil agency cost. Selain itu, dengan adanya utang yang tinggi maka manajer akan mengoperasikan perusahaan dengan lebih efisien, karena adanya kekhawatiran manajer akan ancaman kebangkrutan. Khan, et al (2012) menyatakan bahwa utang dalam struktur modal dapat digunakan untuk mengurangi agency cost. Terdapat hubungan negatif signifikan antara struktur modal terhadap agency cost (Zhang dan $\mathrm{Li}$, 2008). Akan tetapi banyaknya jumlah utang yang dipinjam dapat meningkatkan agency cost. Fachrudin (2011); Lin (2009); Randis dan Fitriany (2014); Ruviah (2015) menemukan pengaruh signifikan positif struktur modal terhadap agency cost. Kim dan Lee (2003; dalamRandis dan Fitriany, 2014) menyatakan konflik agency antara shareholder dan bondholder akan semakin serius ketika perusahaan dalam keadaan financial distress.

H1 : Struktur modal berpengaruh negatif terhadap agency cost.

\subsection{Pengaruh Ukuran Perusahaan terhadap Agency Cost}

Ukuran perusahaan yang besar membutuhkan sedikit beban discretionary. Selain itu, perusahaan yang memiliki ukuran besar cenderung menarik perhatian dan kemungkinan berada dalam observasi publik yang lebih besar, sehingga perusahaan yang memiliki ukuran lebih besar akan mengungkapkan informasi yang lebih luas untuk mengurangi agency cost. Selain itu, semakin besar perusahaan maka semakin banyak karyawan yang dipekerjakan, hal tersebut menyebabkan pemerintah akan memberikan pengawasan yang lebih, untuk melindungi para pekerja dan menyoroti masalah sosial yang terjadi di dalam perusahaan (Firth et al, 2008). Keadaan tersebut menuntut perusahaan yang memiliki tanggung jawab besar kepada publik dan pemerintah, untuk mengoperasikan perusahan dengan profesionalitas yang tinggi, sehingga hal ini akan menurunkan agency cost. Dita (2013); Zhang dan Li (2008); Fachrudin (2011); Randis dan Fitriany (2014) menemukan pengaruh signifikan negatif ukuran perusahaan terhadap agency cost.

$\mathrm{H} 2$ : Ukuran perusahaan berpengaruh negatif terhadap agency cost.

\subsection{Pengaruh Struktur Modal terhadap Kinerja Keuangan}

Modigliani dan Miller (1963; dalam Budiarso, 2013) menyatakan bahwa penggunaan utang dapat mendatangkan keuntungan bagi perusahaan karena adanya tax shield dari pembayaran bunga utang sehingga hal tersebut akan berdampak pada peningkatan kinerja. Selain itu, utang dalam investasi digunakan sebagai tambahan untuk mendanai aset perusahaan. Hal ini diharapkan bahwa utang akan dapat meningkatkan profit perusahaan. Profit yang semakin meningkat akan menarik para investor. Di samping itu, semakin banyak utang dapat diartikan bahwa semakin dinilai bagus kinerja keuangan oleh para kreditor karena kemampuan perusahaan dalam membayar utang. Sehingga perusahaan lebih dipercaya oleh kreditor dalam memberikan pinjaman. Kemampuan membayar utang yang baik mencerminkan operasional di dalam perusahaan yang baik pula. Budiarso (2013); Calisir, et al (2010); dan Dita (2013) menemukan bahwa struktur modal berpengaruh positif terhadap kinerja keuangan. Pratheepkanth (2010) menemukan bahwa struktur modal berpengaruh negatif terhadap kinerja keuangan. Kim dan Lee (2003; dalam Randis dan Fitriany, 2014) menyatakan bahwa utang berpengaruh signifikan terhadap kinerja keuangan saat terjadi krisis.

H3 : Struktur modal berpengaruh positif terhadap kinerja keuangan.

\subsection{Pengaruh Ukuran Perusahaan terhadap Kinerja Keuangan}

Ukuran perusahaan merupakan sebuah skala yang digunakan untuk menggambarkan besar kecilnya suatu perusahaan melalui berbagai cara. Biasanya ukuran perusahaan ditunjukkan oleh total aktiva, jumlah penjualan, rata-rata total penjualan dan rata-rata total aktiva. Perusahaan dengan ukuran yang lebih besar dimungkinkan lebih 


\section{NATIONALLY ACCREDITED J OURNAL - DECREE NO. 21/E/KPT/2018}

mampu melakukan strategi diversifikasi selain itu, perusahaan yang lebih besar memiliki kemampuan yang lebih besar dalam menghadapi pesaing. Faktor ini dapat memberikan pengaruh positif antara ukuran terhadap kinerja keuangan. Taswan dan Soliha (2002; dalam Randis dan Fitriany, 2014) mengemukakan bahwa ukuran perusahaan yang besar dapat merefleksikan tingkat kesejahteraan di masa depan. Dalam penelitian Dogan (2013); Kaen dan Baumann (2003; dalamRandis dan Fitriany, 2014); Oladele dan Adebayo (2013); Ruviah (2015); serta Serrasqueiro dan Nunes (2008) menyatakan bahwa ukuran perusahaan berpengaruh positif terhadap profitabilitas perusahaan. Berbeda halnya dengan hasil penelitian Raharja (2012) yang menyatakan bahwa ukuran perusahaan tidak berpengaruh signifikan terhadap kinerja keuangan. Karena, ukuran perusahaan yang besar belum tentu menghasilkan kinerja keuangan yang lebih baik. Semakin besar aset yang dimiliki perusahaan, memungkinkan semakin kompleks pula masalah agensi yang dihadapi (Kaen dan Baumann, 2003; dalam Randis dan Fitriany, 2014).

$\mathrm{H} 4$ : Ukuran perusahaan berpengaruh positif terhadap kinerja keuangan.

\subsection{Pengaruh Agency Cost terhadap Kinerja Keuangan}

Jensen dan Meckling (1976; dalamBudiarso, 2013) menyatakan bahwa hubungan kontrak yang tidak lengkap antara pemegang saham dan agen dapat menyebabkan masalah keagenan. Secara umum, masalah keagenan dapat menyebabkan hilangnya kekayaan pemegang saham dari aspek kepentingan pribadi, manajemen akan meningkatkan tambahan konsumsi dan perilaku tidak bertanggungjawab yang pada akhirnya akan meningkatkan biaya keagenan. Peningkatan biaya keagenan yang berupa pemberian insentif yang layak kepada para manajer, biaya pengawasan untuk mencegah hazard, serta penggunaan kas untuk bonus dan pengeluaran-pengeluaran lainnya yang tidak perlu akan meningkatkan peningkatan beban perusahaan yang pada akhirnya akan memberikan dampak negatif terhadap kinerja keuangan perusahaan. Penelitian Lin (2009) dan Wright, et al (2009) menemukan bahwa agency cost berpengaruh negatif dan signifikan terhadap kinerja keuangan perusahaan. Artinya bila agency cost membengkak, maka hal tersebut dapat mengurangi pencapaian keuntungan kompetitif yang berdampak negatif terhadap kinerja. Begitu juga halnya dengan Dita (2013); Randis dan Fitriany (2013); serta Xiao (2009) menemukan bahwa agency cost berhubungan negatif dengan kinerja keuangan. $\mathrm{H} 5$ : Agency cost berpengaruh negatif terhadap kinerja keuangan.

\subsection{Pengaruh Struktur Modal melalui Agency Costterhadap Kinerja Keuangan}

Brigham dan Daves (2004; dalam Fachrudin, 2011) menyatakan bahwa penggunaan hutang yang tinggi dalam struktur modal dapat menimbulkan ancaman kebangkrutan sehingga mengurangi agency cost. Dengan berkurangnya agency cost diharapkan kinerja akan meningkat. Berdasarkan Pecking Order Theory menyatakan bahwa perusahaan dengan tingkat profitabilitas yang tinggi justru tingkat hutangnya rendah. Tetapi hutang yang rendah, akan mempengaruhi kebijakan manajer sebagai agen dalam penggunaan aliran kas untuk kepentingan pribadi, yang demikian akan meningkatkan agency cost serta menurunkan kinerja keuangan. Penggunaan hutang dalam struktur modal dapat mendisiplinkan manajer dalam penggunaan aliran kas, dengan demikian biaya menurun yang akhirnya meningkatkan kinerja keuangan. Fachrudin (2011); Randis dan Fitriany (2014) menemukan pengaruh tidak langsung struktur modal melalui agency cost terhadap kinerja keuangan. Struktur modal berpengaruh positif terhadapkinerja perusahaan melalui agency cost sebagai varabel intervening, baik pada perusahaan yang mengalami financial distress dan tidak mengalami financial distress (Marjani dan Surasni, 2016).

H6 : Struktur modal berpengaruh signifikan melalui agency costterhadap kinerja keuangan 


\subsection{Pengaruh Ukuran Perusahaan melalui Agency Costterhadap Kinerja Keuangan}

Kaen dan Baumann (2003; dalam Randis dan Fitriany, 2014) menyatakan bahwa perusahaan yang besar cenderung mempunyai masalah keagenan yang kompleks. Semakin banyak masalah keagenan yang terjadi akan menimbulkan agency cost meningkat, selanjutnya akan mengganggu stabilitas perusahaan kemudian berakibat menurunkan kinerja (Kim dan Lee, 2003; dalam Randis dan Fitriany, 2014). Semakin besar perusahaan maka semakin banyak karyawan yang dipekerjakan (Firth, 2008). Teori organisasi mengungkapkan bahwa ukuran perusahaan berpengaruh terhadap profitabilitas melalui agency cost sebagaimana dikemukakan oleh Jensen dan Meckling (1976; dalam Budiarso, 2013). Zhang dan Li (2008) menyatakan bahwa ukuran perusahaan meningkatkan skala ekonomis maka kemungkinan kinerja akan meningkat melalui pengurangan beban operasional. Selanjutnya Fachrudin (2011) memperoleh bukti yang mendukung teori di atas bahwa ukuran perusahaan berpengaruh tidak langsung terhadap kinerja keuangan perusahaan melalui agency cost sebagai variabel intervening.

H7 : Ukuran perusahaan berpengaruh signifikan melalui agency costterhadap kinerja.

\section{METODE PENELITIAN}

Penelitian ini termasuk penelitian kausalitas, menggunakan pendekatan kuantitatif dengan jenis metode sampel survey. Penelitian ini berusaha untuk membuktikan pengaruh dari struktur modal dan ukuran perusahaan melalui agency cost sebagai variabel intervening terhadap kinerja keuangan. Populasi yang digunakan dalam penelitian ini adalah seluruh perusahaan manufaktur yang terdaftar di Bursa Efek Indonesia (BEI), sedangkan sampel yang digunakan adalah perusahaan manufaktur subsektor Miscellaneous Industry (kelompok industri lainnya) yang terdaftar di BEI dan telah mempublikasikan laporan keuangan tahunan periode 2013-2017. Sampel yang diambil adalah sebanyak 23 perusahaan dengan 115 pengamatan. Teknik pengambilan sampel yang digunakan dalam penelitian ini adalah metode purposive sampling. Model analisis jalur (path analysis) digunakan dalam penelitian ini untuk menganalisis pola hubungan antar variabel dengan tujuan untuk mengetahui pengaruh langsungmaupun tidak langsung seperangkat variabel bebas (eksogen) terhadap variabel terikat (endogen). Analisis jalur ini dilakukan dengan bantuan perangkat lunak komputer SPSS.

\section{HASIL DAN PEMBAHASAN}

\subsection{Analisis Data}

Deskripsi data dalam penelitian ini meliputi 4 variabel yaitu: Debt to Equity Ratio (DER), Firm Size (FS), Agency Cost (AC) dan Price Book Value (PBV). Sebagaimana tercantum dalam Tabel 1, diketahui bahwa data yang digunakan dalam penelitian ini adalah sebanyak 23 sampel data yang diambil dari laporan keuangan tahunan perusahaan manufaktur subsektor Miscellaneous Industry yang Terdaftar di BEI periode 2013-2017.

Tabel 1. Deskripsi Variabel Penelitian pada Perusahaan Manufaktur Subsektor Miscellaneous Industry yang Terdaftar di BEI Periode 2013-2017

\begin{tabular}{lrrrr}
\hline & DER(X) & FS(LN) & SGA(\%) & \multicolumn{1}{c}{ PBV(\%) } \\
\hline$N$ & 115 & 115 & 115 & 115 \\
Mean & 72,09 & 14,78 & 9,44 & 114,28 \\
Median & 77,41 & 14,53 & 7,96 & 89,47 \\
Std. Deviation & 274,03 & 1,60 & 7,22 & 124,95 \\
Minimum & $-2123,43$ & 11,40 & 1,98 & 1,77 \\
Maximum & 890,80 & 19,51 & 37,60 & 1163,52 \\
Sum & 8290,81 & 1700,07 & 1085,05 & 13142,13 \\
\hline
\end{tabular}




\section{NATIONALLY ACCREDITED J OURNAL - DECREE NO. 21/E/KPT/2018}

Untuk mengetahui pengaruh variabel struktur modal dan ukuran perusahaan terhadap agency cost dapat dilihat pada output SPSS yang dirangkum pada Tabel 2 sebagai berikut:

Tabel 2. Hasil Regresi Jalur I

\begin{tabular}{cccccc}
\hline Regression I & R Square & $\begin{array}{c}\text { Standardize } \\
\text { Beta }\end{array}$ & $\boldsymbol{t}$ & Sig. & Keterangan \\
\hline DER $\rightarrow$ AC & 0,433 & $-0,088$ & $-0,996$ & 0,322 & $\begin{array}{c}\text { Tidak } \\
\text { FS } \rightarrow \text { AC }\end{array}$ \\
& & $-0,641$ & $-7,256$ & 0,000 & $\begin{array}{c}\text { Signifikan } \\
\text { Signifikan }\end{array}$ \\
\hline
\end{tabular}

$$
\text { AC }=-0,088 \text { DER -0,641 FS +0,753 } C_{1}
$$

Hasil perhitungan regresi pada Tabel 2 dapat dijelaskan bahwa nilai koefisien regresi variabel struktur modal adalah sebesar $-0,088$. Artinya jika struktur modal meningkat1 satuan, maka agency cost akan berubah mengalami penurunan sebesar 0,088satuan, dengan asumsi variabel lainnya dianggap tetap. Koefisien regresi yang bertanda negatif menunjukkan pengaruh yang berlawanan arah antara struktur modal dengan agency cost. Artinya apabila struktur modal meningkat maka agency cost akan mengalami penurunan, begitu juga sebaliknya. Selanjutnya nilai signifikansi untuk variabel struktur modal adalah sebesar 0,322, artinya bahwa koefisien jalur tersebut tidak signifikan. Jadi ada pengaruh yang negatif tidak signifikan antara struktur modal terhadap agency cost, dengan demikian hipotesis pertama ditolak.

Berikutnya nilai koefisien regresi variabel ukuran perusahaan adalah sebesar -0,641. Artinya jika ukuran perusahaan berubah mengalami peningkatan 1 satuan, maka agency cost akan menurun sebesar -0,641satuan, dengan asumsi variabel lainnya dianggap tetap. Koefisien regresi yang bertanda negatif menunjukkan pengaruh yang berlawanan arah antara ukuran perusahaan dengan agency cost. Artinya apabila ukuran perusahaan meningkat maka agency cost akan mengalami penurunan, begitu juga sebaliknya. Selanjutnya nilai signifikansi untuk variabel ukuran perusahaan adalah sebesar 0,000, artinya bahwa koefisien jalur tersebut terbukti signifikan. Jadi ada pengaruh negatif yang signifikan antara ukuran perusahaan terhadap agency cost perusahaan manufaktur subsektor Miscellaneous Industry yang Terdaftar di BEI periode 2013-2017, yang berarti hipotesis kedua diterima dalam penelitian.

Besarnya angka $R$ Square $\left(\mathrm{r}^{2}\right)$ adalah 0,433 dimana angka tersebut dapat digunakan untuk melihat besarnya pengaruh antara struktur modal dan ukuran perusahaan terhadap agency cost. Angka tersebut mempunyai maksud bahwa pengaruh struktur modal dan ukuran perusahaan terhadap agency cost adalah 43,30 persen. Adapun sisanya sebesar 56,70 persen $(100 \%-43,30 \%)$ dipengaruhioleh faktor lain yang tidak termasuk dalam penelitian.

Tabel 3.Hasil Regresi Jalur II

\begin{tabular}{cccccc}
\hline Regression I & R Square & $\begin{array}{c}\text { Standardize } \\
\text { Beta }\end{array}$ & $\boldsymbol{t}$ & Sig. & Keterangan \\
\hline DER $\rightarrow$ PBV & & 0,013 & 1,143 & 0,257 & Tidak \\
& 0,486 & 0,062 & 4,066 & 0,010 & $\begin{array}{c}\text { Signifikan } \\
\text { FS } \rightarrow \text { PBV }\end{array}$ \\
AC $\rightarrow$ PBV & & $-0,128$ & $-8,385$ & 0,000 & Signifikan \\
\hline
\end{tabular}

PBV = 0,013 DER + 0,062 FS -0,128 SGA +0,717 $\epsilon_{2}$

Nilai koefisien regresi variabel struktur modal adalah sebesar 0,013. Artinya jika struktur modal berubah meningkat 1 satuan, maka kinerja keuangan perusahaan akan berubah meningkat sebesar 0,013 dengan asumsi variabel lainnya tetap. Koefisien regresi yang bertanda positif menunjukkan pengaruh yang searah antara struktur modal dengan kinerja keuangan perusaahan. Artinya apabila struktur modal meningkat maka kinerja keuangan perusaahan akan meningkat juga, begitu sebaliknya. Nilai signifikansi untuk variabel struktur modal adalah sebesar 0,257, artinya bahwa koefisien jalur tersebut terbukti tidak signifikan. Jadi ada pengaruh positif tidak signifikan antara struktur modal terhadap kinerja keuangan perusahaan, yang menunjukkan bahwa hipotesis ketiga ditolak. 


\section{NATIONALLY ACCREDITED J OURNAL - DECREE NO. 21/E/KPT/2018}

Koefisien regresi variabel ukuran perusahaan adalah sebesar 0,062. Artinya jika ukuran perusahaan berubah 1 satuan, maka kinerja keuangan perusahaan akan berubah mengalami peningkatan sebesar 0,062 dengan asumsi variabel lainnya tetap. Koefisien regresi yang bertanda positif menunjukkan pengaruh yang searah antara ukuran perusahaan dengan kinerja keuangan perusaahan. Artinya apabila ukuran perusahaan meningkat maka kinerja keuangan perusaahan akan meningkat, begitu juga sebaliknya. Nilai signifikansi untuk variabel ukuran perusahaan adalah sebesar 0,010, artinya bahwa koefisien jalur tersebut terbukti signifikan. Jadi ada pengaruh positif yang signifikan antara ukuran perusahaan terhadap kinerja keuangan perusahaan, dimana hipotesis keempat yang diajukan dalam penelitian ini diterima atau dapat dibuktikan.

Selanjutnya koefisien regresi variabel agency cost adalah sebesar $-0,128$. Artinya jika agency cost berubah 1 satuan, maka kinerja keuangan perusahaan akan berubah mengalami penurunan sebesar 0,128 dengan asumsi variabel lainnya tetap. Koefisien regresi yang bertanda negatif menunjukkan pengaruh yang berlawanan antara agency cost dengan kinerja keuangan perusaahan. Artinya apabila agency cost meningkat maka kinerja keuangan perusaahan akan menurun, begitu juga sebaliknya. Sedangkan nilai signifikansi untuk variabel agency cost adalah sebesar 0,000, artinya bahwa koefisien jalur tersebut terbukti signifikan. Jadi ada pengaruh signifikan positif antara agency cost terhadap kinerja keuangan perusahaan, dengan kata lain hipotesis kelima diterima.

Besarnya angka $R$ Square $\left(\mathrm{r}^{2}\right)$ adalah 0,486 dimana angka tersebut dapat digunakan untuk melihat besarnya pengaruh antara struktur modal, ukuran perusahaan danagency cost terhadap kinerja keuangan perusahaan sebesar 48,60 persen, sedangkan sisanya sebesar 51,40 persen dipengaruhi oleh faktor lain yang tidak termasuk dalam penelitian ini.

Tabel 4.Perhitungan Pengaruh Tidak Langsung

\begin{tabular}{lcc}
\hline \multicolumn{1}{c}{ Pengaruh Variabel } & Formula Perhitungan & Hasil \\
\hline Rangkuman Pengaruh Langsung (Direct Effect/DE) & & \\
DER terhadap AC & DEX1Z & $-0,088$ \\
FS terhadap AC & DEX2Z & $-0,641$ \\
AC terhadap PBV & DEZY & $-0,128$ \\
Rangkuman Pengaruh Tidak Langsung (Indirect Effect/IE) & \\
DER terhadap PBV melalui AC & DEX1Z x DEZY & 0,011 \\
& $(-0,088 \times-0,128)$ & \\
FS terhadap PBV melalui AC & DEX2Z x DEZY & 0,082 \\
\hline
\end{tabular}

Besarnya pengaruh tidak langsung variabel stuktur modal melalui agency cost terhadap kinerja keuangan perusahaan diperoleh melalui hasil perkalian koefisien jalur (beta) antara pengaruh langsung struktur modal terhadap agency cost dengan pengaruh langsung agency cost terhadap kinerja keuangan perusahaan. Besarnya pengaruh tidak langsung struktur modal melalui agency cost terhadap kinerja keuangan perusahaan yaitu sebesar 0,011 $(-0,088 \times-0,128)$. Sedangkan besarnya pengaruh tidak langsung variabel ukuran perusahaan melalui agency cost terhadap kinerja keuangan perusahaan diperoleh melalui hasil perkalian koefisien jalur (beta) antara pengaruh langsung ukuran perusahaan terhadap agency cost dengan pengaruh langsung agency cost terhadap kinerja keuangan perusahaan. Besarnya pengaruh tidak langsung ukuran perusahaan melalui agency cost terhadap kinerja keuangan perusahaan yaitu sebesar $0,082(-0,641 \times-0,128)$. 
Tabel 5. Rangkuman Hasil Analisis Jalur

\begin{tabular}{cccccc}
\hline Hipotesis & Variabel & t-hitung & Sig. & Alfa & Kesimpulan \\
\hline $\mathrm{H}_{1}$ & DER $\rightarrow$ AC & $-0,996$ & 0,322 & & ditolak \\
$\mathrm{H}_{2}$ & FS $\rightarrow$ AC & $-7,256$ & 0,000 & & diterima \\
$\mathrm{H}_{3}$ & DER $\rightarrow$ PBV & 1,143 & 0,257 & & ditolak \\
$\mathrm{H}_{4}$ & $\mathrm{FS} \rightarrow$ PBV & 4,066 & 0,010 & 0,050 & diterima \\
$\mathrm{H}_{5}$ & $\mathrm{AC} \rightarrow$ PBV & $-8,385$ & 0,000 & & diterima \\
$\mathrm{H}_{6}$ & DER $\rightarrow$ AC $\rightarrow$ PBV & 0,993 & 0,321 & & ditolak \\
$\mathrm{H}_{7}$ & FS $\rightarrow$ AC $\rightarrow$ PBV & 5,489 & 0,000 & & diterima \\
\hline
\end{tabular}

Hasil uji $\mathrm{t}$ dalam Tabel 5 pada perusahaan manufaktur subsektor Miscellaneous Industry yang Terdaftar di BEI periode 2013-2017 untuk jalur I yaitu pengaruh struktur modal (diproksikan oleh variabel DER) terhadap agency cost menunjukkan hasil yang tidak signifikan dikarenakan nilai p-value sebesar 0,322 yang lebih besar jika dibandingkan dengan nilai alfa 5 persen. Sedangkan pada pengaruh ukuran perusahaan(diproksikan oleh variabel FS) terhadap agency cost menunjukkan hasil yang signifikan dikarenakan nilai $p$ value sebesar 0,000 yang lebih kecil dari nilai alfa 5 persen.

Untuk jalur II yaitu pengaruh struktur modal terhadap kinerja keuangan (diproksikan oleh variabel PBV) pada perusahaan manufaktur subsektor Miscellaneous Industry yang terdaftar di BEI periode 2013-2017 menunjukkan hasil yang tidak signifikan dikarenakan nilai $p$-value sebesar 0,257 lebih besar dari nilai alfa 5 persen. Berbeda halnya dengan pengaruh ukuran perusahaan terhadap kinerja keuangan perusahaan menunjukkan hasil yang positif dan signifikan dikarenakan nilai p-value sebesar 0,010 lebih kecil dari nilai alfa 5 persen. Agency cost berpengaruh negatif dan signifikan terhadap kinerja keuangan.

Pengujian hipotesis ke-6 dilakukan menggunakan uji signifikansi dengan membandingkan nilai probabilitas signifikansi sebesar 0,050 . Diketahui nilai probabilitas signifikansi sebesar 0,320 atau lebih besar dari 0,050 (0,320>0,050). Dengan demikian, diketahui bahwa agency cost bukan merupakan variabel intervening antara struktur modal dan kinerja keuangan perusahaan, sehingga hipotesis keenam yang menyatakan "struktur modal berpengaruh signifikan melalui agency cost sebagai variabel intervening terhadap kinerja keuangan perusahaan" ditolak. Dapat diketahui untuk pengaruh tidak langsung variabel DER terhadap agency cost dan PBV pada perusahaan manufaktur subsektor Miscellaneous Industry yang Terdaftar di BEI periode 2013-2017 adalah tidak signifikan.

Besarnya pengaruh ukuran perusahaan terhadap kinerja keuangan perusahaan dengan agency cost sebagai variabel intervening pada perusahaan manufaktur kelompok lainnya yang terdaftar di BEI tahun 2013-2017. Hasil uji Sobel menunjukkan nilai Sobel Test Statistic sebesar 5,489 dengan nilai probabilitas signifikansi sebesar 0,000 atau lebih kecil dari $0,050(0,000<0,050)$. Dengan demikian, diketahui bahwa variabel agency cost merupakan variabel intervening antara ukuran perusahaan dan kinerja keuangan perusahaan, sehingga hipotesis ketujuh yang menyatakan "ukuran perusahaan berpengaruh signifikan melalui agency cost sebagai variabel intervening terhadap kinerja keuangan perusahaan" dapat diterima. Secara keseluruhan dapat diketahui pengaruh tidak langsung variabel FS terhadap agency cost dan PBV pada perusahaan manufaktur subsektor Miscellaneous Industry yang Terdaftar di BEI periode 2013-2017 terbukti signifikan.

\subsection{Pembahasan}

\subsubsection{Pengaruh Struktur Modal (DER) terhadap Agency Cost(SGA)}

Pengujian hipotesis pertama menemukan bahwa struktur modal berpengaruh negatif tidak signifikan terhadap agency cost. Artinya penggunaan hutang pada perusahaan tidak berdampak banyak terhadap usaha manajemen dalam menekan agency cost. Temuan ini mengemukakan bahwa rata-rata rasio hutang terhadap ekuitas adalah 72,09 persen dengan 


\section{NATIONALLY ACCREDITED J OURNAL - DECREE NO. 21/E/KPT/2018}

standar deviasi 274,03 . Jumlah yang tinggi ini mengindikasikan bahwa perusahaan sedang dalam kesulitan keuangan sehingga terdapat kemungkinan bahwa manajer tidak berhatihati dalam pengeluaran discreationary expense, karena itu pengaruh struktur modal terhadap agency cost menjadi negatif. Hal ini sejalan dengan temuan Khan, et al (2012) yang menyatakan bahwa terdapat pengaruh negatif antara struktur modal dan agency cost. Banyaknya jumlah hutang yang dipinjam dapat menurunkan agency cost. Temuan menunjukkan bahwa jika hal-hal lain dianggap tetap, peningkatan hutang sebesar 1 persen akan menurunkan proksi agency cost, dalam hal ini adalah perbandingan discretionary expense dengan penjualan bersih sebesar 0,088 persen, sangat rendah sekali dampak yang ditimbulkan. Kemungkinan hal ini terjadi karena beban bunga hutang yang meningkat seiring dengan meningkatnya jumlah hutang.

\subsubsection{Pengaruh Ukuran Perusahaan (FS) terhadap Agency Cost(SGA)}

Ukuran perusahaan berpengaruh negatif terhadap agency cost. Koefisien unstandardized beta -0,641 menunjukkan bahwa jika hal-hal lain dianggap tetap, peningkatan ukuran perusahaan sebesar 1 persen akan menekan agency cost sebesar 0,641 persen. Dengan demikian, keadaan tersebut menuntut perusahaan yang memiliki tanggung jawab besar kepada publik dan pemerintah, untuk mengoperasikan perusahan dengan profesionalitas yang tinggi, sehingga hal ini akan menurunkan agency cost. Hasil uji ini sesuai dengan temuan Dita (2013); Zhang dan Li (2008); Fachrudin (2011); Randis dan Fitriany (2014) menemukan pengaruh signifikan negatif ukuran perusahaan terhadap agency cost. Indikasinya adalah bahwa manajemen akan melakukan pengelolaan aset yang lebih kompleks yang dapat berakibat pada penurunan tingkat efisiensi. Perusahaan yang memiliki ukuran besar cenderung menarik perhatian dan kemungkinan berada dalam observasi publik yang lebih besar, sehingga perusahaan yang memiliki ukuran lebih besar akan mengungkapkan informasi yang lebih luas untuk mengurangi agency cost.

\subsubsection{Pengaruh Struktur Modal (DER) terhadap Kinerja Keuangan (PBV)}

Struktur modal berpengaruh positif tidak signifikan terhadap kinerja keuangan perusahaan. Pada perusahaan yang tidak mengalami masalah keuangan, perusahaan akan lebih efektif menggunakan profit untuk pendanaan (Pecking Order Theory). Kondisi pada perusahaan objek diindikasikan telah menerbitkan hutang yang oleh manajer perusahaan telah digunakan secara bijak. Penggunaan hutang yang tepat terjadi ketika manajer membuat keputusan investasi yang menguntungkan. Hal tersebut ditandai dengan adanya peningkatan harga saham yang ekstrem selama periode pengamatan yang terjadi pada beberapa perusahaan sampel. Penelitian ini juga menemukan hasil yang sama sebagaimana penelitian Calisir, et al (2010); Dita (2013); dan Budiarso (2013) yang menyatakan struktur modal berpengaruh positif terhadap kinerja keuangan. Perusahaan yang dapat menggunakan hutang untuk operasional secara efektif dan efisien akan meningkatkan kinerja keuangannya. Perusahaan yang sebagian besar pembiayaannya bergantung pada hutang mengakibatkan perusahaan membayar jumlah beban pajak yang rendah. Perusahaan yang dapat menggunakan hutang untuk operasional secara efektif dan efisisen akan meningkatkan kinerjanya.

\subsubsection{Pengaruh Ukuran Perusahaan (FS) terhadap Kinerja Keuangan (PBV)}

Ukuran perusahaan signifikan positif mempengaruhi kinerja keuangan perusahaan. Hasil yang positif dan kuat ini disebabkan oleh penggunaan aset-aset yang dimiliki perusahaan oleh pihak manajemen secara efisien. Pernyataan tersebut didukung oleh bukti yang ditunjukan oleh elemen pembentuk PBV yaitu rasio peningkatan harga jual saham pada perusahaan manufaktur subsektor Miscellaneous Industry yang Terdaftar di BEI. Ratarata rasio PBV perusahaan manufaktur yang menjadi sampel dalam penelitian ini memiliki kecenderungan meningkat selama periode 2013-2017. Hal ini menunjukkan bahwa asetaset yang dimiliki oleh perusahaan sudah dapat dimaksimalkan menjadi penjualan. 


\section{NATIONALLY ACCREDITED J OURNAL - DECREE NO, 21/E/KPT/2018}

Ukuran perusahaan yang besar dapat merefleksikan tingkat kesejahteraan di masa depan (Taswan dan Soliha, 2002; dalam Randis dan Fitriany, 2014). Temuan ini sejalan dengan hasil penelitian Serrasqueiro dan Nunes (2008); Dogan (2013); Oladele dan Adebayo (2013); serta Ruviah (2015) yang menyatakan bahwa ukuran perusahaan berpengaruh positif terhadap kinerja keuangan perusahaan. Hasil temuan ini menunjukkan bahwa walaupun penelitian dilakukan pada lokasi, objek dan periode yang berbeda tapi memberikan hasil yang sama merupakan suatu indikasi bahwa total aktiva adalah faktor yang menentukkan dalam pencapaian tujuan perusahaan yaitu kinerja keuangan.

\subsubsection{Pengaruh Agency Cost (SGA) terhadap Kinerja Keuangan (PBV)}

Pada hasil penelitian menunjukkan nilai koefisien untuk agency cost dalam penelitian ini yang diproksikan dengan (Sales, General\& Administrative Expense, atau SGA Expense) bernilai negatif dengan tingkat signifikansi lebih kecil dari alfa 5 persen. Sehingga pengujian hipotesis kelima $\left(\mathrm{H}_{5}\right)$ menemukan bahwa agency cost berpengaruh negatif dan signifikan terhadap PBV. Besarnya agency cost yang dikeluarkan oleh perusahaan untuk mengatasi agency problem dapat memengaruhi kinerja keuangan. Temuan ini menunjukkan bahwa agency cost yang dikeluarkan oleh perusahaan nilainya tidak wajar atau dibiarkan membengkak sehingga menurunkan kinerja keuangan. Hal ini dikarenakan discretionary expense terhadap penjualan bersih semakin tinggi sehingga tingkat pengembalian atas modal semakin rendah. Meningkatnya agency cost maka tingkat pengembalian modal perusahaan akan rendah. Hal ini sejalan dengan Lin (2009) dan Wright et al (2009) dalam Fachrudin (2011) yang menemukan bahwa agency cost berpengaruh negatif dan signifikan terhadap kinerja keuangan perusahaan, artinya bila agency cost meningkat maka dapat mengurangi kinerja keuangan. Pada perusahaan yang mengalami masalah keuangan, agency cost yang semakin tinggi mencerminkan bahwa semakin kompleks konflik keagenan yang terjadi dalam perusahaan, kemudian berdampak negatif pada kinerja keuangan.

\subsubsection{Pengaruh Struktur Modalterhadap Kinerja Keuangan melalui Agency Cost}

Dari hasil pengujian path analysis untuk Jalur I dan Jalur II pada perusahaan manufaktur subsektor Miscellaneous Industry yang Terdaftar di BEI periode 2013-2017, nilai koefisien dari variabel struktur modal terhadap agency cost negatif dengan nilai $p$-value yang lebih besar dari 5 persen. Hal ini berarti bahwa hipotesis keenam $\left(\mathrm{H}_{6}\right)$ dalam penelitian ini ditolak. Berdasarkan hasil uji tersebut diketahui bahwa struktur modal berpengaruh negatif tidak signifikan terhadap agency cost, dan variabel agency cost berpengaruh negatif dan signifikan terhadap kinerja keuangan perusahaan. Koefisien pengaruh tidak langsung dari struktur modal melalui agency cost terhadap kinerja keuangan perusahaan adalah positif, sehingga struktur modal berpengaruh positif melalui agency cost terhadap kinerja keuangan pada perusahan manufaktur kelompok industri lainnya yang terdaftar di BEI periode 2013-2017. Melihat hasil pengaruh langsung model mediasi dari struktur modal terhadap kinerja keuangan perusahaan adalah tidak signifikan, serta terdapat pengaruh mediasi (tidak langsung) yang tidak signifikan, maka dapat dimaknai mediasi yang terjadi adalah mediasi penuh (complete mediation). Efek mediasi terdapat dalam model dan koefisien pengaruh langsung struktur modal terhadap kinerja keuangan perusahaan tidaksignifikan yang berarti ada pengaruh yang lemah bila dilihat dari nilai koefisien pengaruh langsung. Sedangkan berdasarkan pengaruh tidak langsung model penelitian, maka dapat dikatakan model mediasi dalam penelitian ini adalah konsisten dan berpengaruh positif. Hal ini sejalan dengan temuan Marjani dan Surasni (2016) yang menyatakan struktur modal berpengaruh positif terhadap kinerja perusahaan melalui agency cost sebagai varabel intervening, baik pada perusahaan yang mengalami financial distress dan tidak mengalami financial distress. 


\subsubsection{Pengaruh Ukuran Perusahaan terhadap Kinerja Keuangan melalui Agency Cost}

Berdasar hasil penelitian dilihat dari p-value diketahui bahwa variabel agency cost berpengaruh negatif terhadap kinerja keuangan perusahaan, ukuran perusahaan terhadap agency cost berpengaruh negatif secara signifikan, dan ukuran perusahaan terhadap kinerja keuangan berpengaruh positif secara signifikan. Hal tersebut menunjukkan bahwa terdapat pengaruh tidak langsung antara ukuran perusahaan melalui agency cost sebagai variabel intervening terhadap kinerja keuangan. Agency cost berpengaruh signifikan terhadap kinerja pada alfa 5 persen. Ukuran perusahaan secara langsung memiliki pengaruh signifikan terhadap kinerja keuangan perusahaan. Demikian juga secara tidak langsung, terdapat pengaruh signifikan melalui agency cost terhadap kinerja keuangan perusahaan. Penelitian menghasilkan pengaruh variabel ukuran perusahaan terhadap variabel agency cost signifikan dan pengaruh variabel agency cost terhadap variabel kinerja keuangan perusahaan juga signifikan, sehingga dapat disimpulkan bahwa agency cost memediasi sebagian pengaruh ukuran perusahaan terhadap kinerja keuangan perusahaan. Hal ini sesuai dengan teori menurut Baron dan Kenny (1986; dalam Hadinata et al, 2019) mediasi semu/sebagian (partially mediated) akan terjadi apabila pengaruh variabel pemediasi terhadap variabel dependen signifikan demikian pula pengaruh variabel independen terhadap dependen adalah signifikan. Dalam penelitian ini dapat disimpulkan bahwa agency cost sangat kuat dalam memediasi pengaruh ukuran perusahaan terhadap kinerja keuangan perusahaan.

\section{KESIMPULAN}

Struktur modal berpengaruh negatif tidak signifikan terhadap agency cost. Ukuran perusahaan berpengaruh negatif secara signifikan terhadap agency cost. Struktur modal berpengaruh positif tidak signifikan terhadap kinerja keuangan perusahaan. Ukuran perusahaan berpengaruh positif secara signifikan terhadap kinerja keuangan. Agency cost berpengaruh negatif dan signifikan terhadap kinerja keuangan. Terdapat pengaruh tidak langsung yang tidak signifikan antara struktur modal melalui agency cost terhadap kinerja keuangan perusahaan. Secara langsung struktur modal juga berpengaruh tidak signifikan terhadap kinerja keuangan. Ukuran perusahaan berpengaruh signifikan terhadap kinerja keuangan perusahaan baik secara langsung maupun tidak langsung melalui mediasi agency cost. Model pengaruh tidak langsungnya adalah partially mediated.

Dari hasil penelitian diperoleh implikasi kebijakan bahwa variabel yang paling dominan mempengaruhi kinerja keuangan perusahaan adalah rasio agency cost. Oleh karena itu pemegang saham dalam hal ini pemilik perusahaan harus dapat mengontrol perilaku dari para manajer sehingga beban-beban yang dikeluarkan memang benar-benar beban yang akan meningkatkan penjualan dan pada akhirnya dapat meningkatkan kinerja keuangan.

\section{DAFTAR PUSTAKA}

Budiarso, N.S. (2013). Struktur Modal dan Kinerja Perusahaan (Studi pada Perusahaan yang Terdaftar di Bursa Efek Indonesia Periode 2011-2012). Jurnal Akuntansi dan Keuangan.

Calisir, F., Gumussoy, C.A., Bayraktaroglu, A.E., dan Deniz, E. (2010). Intellectual Capital in the Quoted Turkish ITC Sector. Journal of Intellectual Capital.

Dita, A.R. (2013). Analisis Pengaruh Struktur Modal, Ukuran Perusahaan dan Agency Cost terhadap Kinerja Perbankan yang Terdaftar di Bursa Efek Indonesia. Jurnal Akuntansi UPN Veteran. 
NATIONALLY ACCREDITED J OURNAL - DECREE NO. 21/E/KPT/2018

Fachrudin, K.A. (2011). Analisis Pengaruh Struktur Modal, Ukuran Perusahaan, dan Agensi Cost terhadap Kinerja Perusahaan. Jurnal Akuntansi dan Keuangan.

Firth, M.F., Peter, M.Y., dan Rui, O.M. (2008). Ownership, Governance Mechanisms, and Agency Cost in China's Listed Firm. Journal of Asset Management.

Hadinata, L.J.F., Surati., dan Suparman, L., (2019). Pengaruh Gaya Kepemimpinan Transformasional dan Iklim Organisasi Terhadap Employee Engagement Serta Dampaknya Terhadap Organizational Citizenship Behavior (Studi Sekretariat Daerah Provinsi NTB). Jurnal Magister Manajemen.

Immanuela, I. (2014). Pengaruh Kepemilikan Manajerial, Struktur Modal, Ukuran Perusahaan dan Agency Cost sebagai Variabel Intervening terhadap Kinerja Perusahaan pada Perusahaan Manufaktur yang Terdaftar di BEI. Jurnal Widya Warta.

Khan, M., Kaleem, A., dan Nazir, M.S. (2012). Impact of Firm Capital Structure Decision on Debt Agency Problem: Evidence for Pakistan. Journal of Basic and Applied Scientific Research.

Lin, K.L. (2009). Study on Related Party Transaction with Mainland China in Taiwan Enterprises. Dissertation Management Departemen. Guo Li Cheng Gong University, China.

Marjani, L., dan Surasni, N.K. (2016). Pengaruh Struktur Modal Terhadap Kinerja Perusahaan dengan Agency Cost sebagai Variabel Intervening pada Perusahaan Manufaktur yang Mengalami Financial Distress dan Tidak Mengalami Financial Distresss. Jurnal Magister Manajemen.

Pratheepkanth, P. (2010). Capital Structure and Financial Performance: Evidence from Selected Business Companies in Colombo Stock Exchange Sri Lanka. Journal of Arts, Science, and Commerce.

Raharja, I.B. (2012). Pengaruh Good Governance dan Ukuran Perusahaan terhadap Kinerja Perusahaan (Studi Empiris pada Perusahaan yang Terdaftar di BEI 2010). Diponegoro Journal of Accounting.

Randis, A., dan Fitriany, A. (2014). Analisis Pengaruh Struktur Modal, Kepemilikan Manajerial, dan Ukuran Perusahaan terhadap Kinerja Perusahaan melalui Agency Cost sebagai Variabel Intervening: Perbandingan Perusahaan yang Mengalami Financial Distress dan Tidak. Simposium Nasional Akuntansi (SNA) XVII Mataram.

Ross, S.A., Randolph, W.W., dan Jaffe, J.F. 2008. Corporate Finance 6th Edition, New York: McGraw-Hill.

Ruviah, K.N. (2015). Pengaruh Struktur Modal, Ukuran Perusahaan, Kepemilikan Manajerial dan Agency Cost sebagai Variabel Intervening terhadap Kinerja Perusahaan (Studi Empiris pada Perusahaan Manufaktur yang Terdaftar di Bursa Efek Indonesia Tahun 2011-2013). Jurnal Ekonomi dan Bisnis Unmuh Surakarta.

Xiao, S. (2009). How do Agency Cost Affect Firm Value? Evidence from China. Journal of Economic Literature.

Zhang, H., dan Li., S. (2008). The Impact of Capital Structure on Agency Cost: Evidence from UK Public Companies. Journal of Economic Literature. 